\title{
THEORETICAL INVESTIGATION FOR THE FAILURE OF LEHMAN BROTHERS AND MERRIL LYNCH: A LESSON FOR BANKING INSTITUTIONS IN NIGERIA
}

\section{Andabai Priye Werigbelegha (Ph.D)}

\author{
Department of Banking and Finance, Niger Delta University, Bayelsa State.
}

Phone No: 08037046538, E-mail: priyehc@yahoo.com

Cite this article:

Andabai Priye Werigbelegha (2021), Theoretical

Investigation for the Failure of Lehman Brothers and Merril

Lynch: A Lesson for Banking Institutions in Nigeria. African Journal of Accounting and Financial Research 4(2), 8893. DOI: $10.52589 / A J A F R-$ S9JEWHY3.

\section{Manuscript History \\ Received: 2 Oct 2020 \\ Accepted: 22 Oct 2020 \\ Published: 30 June 2021}

Copyright $\odot 2020$ The Author(s). This is an Open Access article distributed under the terms of Creative Commons AttributionNonCommercial-NoDerivatives 4.0 International (CC BY-NC-ND 4.0 ), which permits anyone to share, use, reproduce and redistribute in any medium, provided the original author and source are credited.
ABSTRACT: The study theoretically examines the failure of Lehman Brothers and Merril Lynch as a lesson for the banking institutions in Nigeria. Hence, the instability experience in the Nigeria financial system in recent time; especially, banking subsector was as a result of institutional failure. Banking experts in Nigeria viewed that the failure of the two banks was an enough signal to the Nigerian banking industry. Hence, the study reveals that the two banks were absolutely limited to the size and age in determining their future instead of depending on the effectiveness and efficient management of risky assets. Hence, the conventional lending procedures are not instituted; rather than depending on subprime mortgage arrangement that has no collateral securities. The declining home prices has make refinancing more difficult as a result of inadequate innovations in securitization. The recommends that the regulatory authorities should not only relied on the conventional tools of bank supervision, but, they should employ more non-conventional methods of obtaining classified information. The financial institutions should train and retrain their employees to meet the current reality on ground. The conventional lending procedures should be instituted rather than depending on subprime mortgage management that did not have collateral securities. The Central Bank of Nigeria (CBN) should be proactive to ensure effective supervision and risk management principles.

KEYWORDS: Failure, Lehman Brothers, Merril Lynch, Lesson, Nigerian, Banking Industry. 


\section{INTRODUCTION}

The study conducted by Andabai (2017) reveals that the future of a bank does not only limited to the size and age; but, also depend on the efficient and effective management of risky assets of a bank. However, Lehman Brothers was found in 1850 as a commodity trader and broker; and, veered into investment banking in 1899 . The institution had a capital base of $\$ 639$ billion with 26,189 employees. The work of Ogoun, Ogiriki and Andabai (2016) stated that the company was specialized in investment banking, equity, fixed income sales, research, trading, investment, management and private equity and private banking. Subsequently, the bank was a primary dealer in the United State America treasury securities market; while, Merrill Lynch was founded in 1914. The institution had a capital base of $\$ 32$ billion and total assets of $\$ 1.6$ trillion. A theoretical study by Nzotta (2014) observed that the bank reputed to be the largest securities firm in the world, with offices in over 98 cities and membership of 28 stock exchanges; the company had about 60,000 staff around the world. On September $14^{\text {th }}$ and $15^{\text {th }}$ 2008 to be more precise; the raging fire of financial crises in United State of America as at that period took an unexpected dimension, when the two banking giants were consumed.

The study conducted by Andabai (2018) noted that age and size alone cannot prevent a bank from failure; but, effective and efficient management of risky assets must remain focused and professional. The study carried out by Ogiriki and Andabai (2017) discovered that bank failure means different thing to different people. However, some are of the view that bank's only fails when it ceases operations even when it has not been officially declared liquidated. Hence, other studies such as Dauladi (2017), Akomolate (2018) and Ajiboye (2018) stated that a bank is failed, when it fails to achieve the purpose for which it was formed. Study by Aniekan and Babalola (2018) reaffirmed that bank fails only when it ceases operations even when it has not been officially being liquidated. Whereas, others view that a bank has failed, if it has not been able to achieve for which it was formed. On the basis of the subject matter, the work of Ezelueli (2018) posited that bank failure is a situation where a bank ceases operation as well as not been able to meet depositors' obligations. In the work of Emene (2017) further stressed that these obligations include: customers, shareholders as well as the community in which it is established. Olagunju (2018) in his own view described bank failure as a situation where there is irremediable bank distress and bank license is revoked and is subsequently liquidated. Anosike (2018) also agreed that a bank has failed when it is liquidated for inability to meet its obligations to creditors.

\section{Theoretical Issues}

Study investigated by Andabai (2018) asserted that bank failures in emerging financial system had serious effects on their economies; and, even when crisis was managed, the cost of distortion of resource allocation is enormous. Hence, restructuring and recapitalization of banks' as a result of the crises becomes a burden to these economies for many years. However, the work conducted by Imoughele and Ismaila (2017) viewed bank failure as a situation of complete or loss of shareholders' funds combined with a cessation of independent operation or by virtue of financial system liquidation. Also Emiaso (2016) noted that a bank is said to have failed if it has not succeeded in achieving any of the objectives for which it was established. Thus, these studies above considered a bank failure as not when it ceases operation but also when it cannot meet its obligations. Ikeora (2016) stressed that these obligations are dues, first and foremost, to its customers as well as to its shareholders and even the community in which 
it operates. The critical importance of banks in economic growth and development explain why each economy seeks measures to prevent such failure.

Hence, Ezelueli (2018) stated that despite the preventive measures, most economies experienced various degrees of bank failure at one time or the other such as in Nigeria. While the cessation of operation by banks is always considered as serious; because, the inability of the banks to meet their maturing obligation as at when due may constitute serious. Bank failure also means the inability of bank to meet maturing obligations, since the inception of banking in Nigeria. Some of the banks breaches these obligations as a result of inaccessibility of Nigerians to banking systems as well as delays and inefficiency in rendering such services thereby encouraging many Nigerians to patronize the informal financial sector that lead to loss of confidence in banks. To this extent the banks could be said to have failed in meeting their obligation or expectations for their establishment. However, the inability of banks to meet obligations, which include to meet depositors demand for withdrawals, persistent losses and outright liquidation.

The work of Ogoun, Ogiriki and Andabai (2016) stated that another danger posed by bank distress is the threat to an efficient payment mechanism and settlement of transactions that are predominantly cash-based with associated risks in the economy. Also, the effectiveness of monetary policy had reduced as a result of direct proportion to the extent of loss of confidence in the banking system as reflected because of instability that characterize the demand for money. Consequently, the proportion of money in circulation outside the banking system had seems to have increased as banks no longer serve as safe custodian of money. In Nigeria today, it is puzzling that in spite of the global trend towards credit based economies and the growth of this culture in most emerging markets, most economies transactions in the economy are carried out on a cash and carry basis. This phenomenon account for the huge pool of total money supply and a good proportion of this represents idle fund that could have been effectively utilized in the productive sector if the banking system is stable, safe and sound.

Theoretical study by Nzotta (2014) posited that the cash based nature of an economy does not only affect the development of the financial institutions; but, also encourages distortion in money supply and macro-economic management. Consequently, the financial cost would be incurred by the economy in order to resolve the problem of distress and this invariable narrowed down to tax the payers at large. The implication would even be more severe for a depressed economy that is already on the path of declining growth. In addition to the theoretical implications of banks credit as a result of bank failure, the expenditures of economic agents are constrained by the quantity of credit made available to them. Thus, this development will reduce the total quantity of credit or disrupts the operations of banks as intermediaries and this will affect the aggregate performance of the economy. In fact, financial intermediation including, credit granting activities of banks and aggregate economic activities will be negatively affected (Anosike, 2018).

The work of Babajide (2008) also revealed that following a string of losses arising from exposure to the trouble United State of America subprime market, on the $15^{\text {th }}$ of September 2008, Lehman Brother filed for bankruptcy. Andabai (2018) posited that while on the $14^{\text {th }}$ of September 2008, Merrill Lynch was also acquired by Bank of America in s $\$ 50$ billion all stock transactions. Consequently, the failure of the two venerable banking institutions shook the entire world financial market with the New York Exchange going down by 504 points. Opara (2017) concluded that in order to be among the biggest investment banks, the two institutions 
were also considered to be the oldest. Aliyu (2017) remarked that the fall of the two banks confirmed what he had always said that banks are sustained by the quality of assets and prudence management of risky assets and not the amount of capital. Because no matter how much capital a bank has, poor assets quality will bring it down one day in fact, he observed that, the two banks were bigger than all the 22 banks in Nigeria.

Study by Ezelueli (2018) observed that Nigeria banks were not panic about the failure of Lehman Brothers and Merrill Lynch. Because, it will have no effect on our economy or any impact in Nigeria Banks, except when there are direct financial dealings. Chiwendu (2018) maintained that Nigerian banks should be cautious about lending at inter-bank market and also be cautions with consumer credits particularly now that liquidity is poor. The global financial crises initially seem not to have crossed border to Nigeria but in the last few weeks of that period (2008) we experienced rubbles because of the stock market. When the prices in the stock market were buoyant, no one looked at the underlying transactions, the balance sheets and fixed income flows from abroad and these flows were moving out slowly while the domestic market has tight liquidity (Andabai, 2018).

The work carried out by Babajide (2008) confirmed that the crises that consumed the two banks were popularly known as the subprime mortgage crises that started with the busting of the United States of America, housing bubble and high default rate on "subprime" and other adjustable-rate mortgages (ARM) that made higher risk borrower with lower income or lesser credit history than "prime" borrowers in 2006. Sanusi (2016) stressed that the term subprime lending refers to the practice of making loans to borrowers who do not qualify for market interest rates owing to various risk such as income level, size of the down payment made, credit history and employment status. Balogun (2018) maintain that the crises can also be attributed to a number of factors such as: the inability of home owners to make their mortgage payments, prejudgment by the borrowers or the lenders. Kayode (2018) stated that further declining home prices had also made refinancing more difficult as a result of innovations in securitization and risk related to inability of home owners to meet mortgage payments that have been distributed broadly, with a series of consequential impacts.

The work of Ahime (2018) posited that the loan incentives and long term trend of rising housing prices encouraged borrowers to assume mortgage, believing that they would be able to refinance at more favourable terms later. However, once housing prices started to drop drastically in 2006 to 2007 in many parts of America, refinancing became more different. Ezelueli (2018) confirmed that as a result default and foreclosure activity increased dramatically as ARM interest rate becomes higher. Hence, in 2008, nearly 1.3 million American housing properties were subject to foreclosure activity up to $79 \%$ from 2006. Babajide (2008) stated that the mortgage lenders that retained credit risk were the first to be affected, as borrowers became unable or unwilling to make payments as at when due. Therefore, major banks and other financial institutions around the world had report losses of approximately $\$ 435$ billion in July 2008 . In summary the major reason for failure was as a result of compromising with the management of risky assets.

Andabai (2018) stressed that the demise of Lehman Brothers and Merrill Lynch had further confirmed the fact that no bank or financial institution is too big to fail. Khacances (2018) stated that Bank of Credit and Commerce International (BCCI), which collapsed in 1991 and Barings Bank which also failed in 1995 are classical examples in this regard. In fact, they could not believe that the raging financial crises that consumed Lehman Brothers and Merrill Lynch 
as both had survived the earlier crises; especially, the great Wall Street crashed of 1920s. However, he also stressed that the massage for Nigerian banks is the fact that both banks failed due to undue credit exposure to the mortgage sector subprime market though mortgage backed securities. That means, the future of a bank depends on the efficient and effective management of risky assets and not the size and age of a bank. Thus, Ekpenyong (2010) emphasized that Nigerian banks should not compromise with the management of risky assets as experienced by the two naming agents.

\section{CONCLUSION AND RECOMMENDATIONS}

The study concluded that the future of a bank does not limited to the size and age; but, depend on the effective and efficient management of risky assets. The declining home prices had made refinancing more difficult as a result of inadequate innovations in securitization. The study therefore recommends that the regulatory authorities should not only relied on the conventional tools of bank supervision, but, they should employ more non-conventional methods of obtaining classified information. The financial institutions should train and retrain their employees to meet the current reality on ground. The conventional lending procedures should be instituted rather than depending on subprime mortgage management that did not have collateral securities. The Central Bank of Nigeria (CBN) should be proactive to ensure effective supervision and risk management principles.

\section{Contribution to Knowledge}

The study was able to expanded the existing contemporary literature that will enable researchers and scholars to use it for further studies. Thus, the study contributed to knowledge by revealing that the future of a bank does not limited to the size and age; but, depend on the effective and efficient management of risky assets of a bank.

\section{REFERENCES}

Andabai, Priye W \& Bingilar, Paymaster Frank (2015). Deposit mobilization and behaviour of banks in Nigeria. International Journal of Advanced Studies in Business Strategies and Management, 3(1), 243-255.

Andabai, Priye W \& Jessie, I. C (2018). Microfinance banks' credit and the growth of small and medium scale business in Nigeria (1990-2016): Investigating the nexus. Journal of Economics and Sustainable Development, 9(6), 28-33.

Andabai, Priye W, Gbalam, E. P \& Egoro Stephen, A (2017). Bank failure in Nigeria: An empirical investigation. Journal of Finance, Banking and Investment, 4(2), 79-96.

Andabai, Priye W. (2017). Post-Consolidation and banks' profitability in Nigeria: Investigating the nexus. Research Journal of Finance and Accounting, 8(24), 133-139.

Aniekan, O. A \& Babalola, S. J. (2018). Banking sector credit and economic growth in Nigeria. CBN Journal of Applied Statistics, 2(2), 34-45.

Anosike, D. F. (2018). Credit facilities in the financial institutions for financing construction projects in Nigeria. Journal of Social Sciences and Management Research, 3(10), 17 27. 
Babajide, Komolafe (2008) Lehman brother failure: A lesson for Nigerian Banks Financial Vanguard, 22 ${ }^{\text {nd }}$ September.

Brown, Q. (2018). Liquidity management and the growth of the economy in Nigeria. International Journal of Research in Commerce and Management, 11(6), 13-23.

Bunde, D \& Aliyu, D. (2017). Effect of bank liquidity management on profitability, Asian Journal of Business Management and research. 6(5), 1019.

Dourati, S (2018). Bank deposit and Liquidity management in Nigeria. Asian Journal of Business Management, 9(11), 234-239.

Ebhodaghe, J. U. (2003). Safe and sound banking practice in Nigeria: Selected Essays. Lagos: Page Publishers Services Ltd.

Ebueju, D. V. (2017). The causes of bank failures and persistent distress in the banking industry. International Journal of Banking and Investment, 8(8), 179-196.

Ekpenyong, D. B. (2010). Financial distress in banks: Nature and implications. Lagos: The Nigerian Bankers.

Emene, J. (2018). The imperatives of regulation of financial institutions: Matters arising. A Paper Presented at CBN $8^{\text {th }}$ Bankers Conference Enugu.

Ibenta, Steve, N. O. (2012). Research monograph: Guidelines for seminar papers, these \& project reports. Awka, Anambra State: Mount Carmel Printing and Publishing.

Ikeora, E. J. (2017). Monetary Theory and Policy in a Developing Economy. Cape Publishers International Limited. Wuse Phase 2, Abuja, Nigeria.

Ikeora, E. J. (2018). Bank Lending, Principles and Practice. Book Point Ltd, Abbot Communications, 71 Old Market Road, Onisha, Anambra State.

Imoughele, L. E. \& Ismaila, M. (2017). The impact of bank credit on growth of small and medium scale enterprises: Econometric evidence from Nigeria. Journal of Educational Policy and Entrepreneurial Research, 1(2), 254-261.

Khacances, D (2018). Threshold effects in the relationship between inflation and growth. IMF Staff Papers, 4(8), 1-21.

Nzotta, S. M. (2014). Money, banking and finance: Theory and practice. Owerri; Imo State: Hudson-Jude Nigeria Publishers.

Stanley Ogoun, Tonye Ogiriki \& Andabai, Priye W. (2016). Banking sector reforms and the performance of Nigerian economy: A vector error correction investigation (VECM). Journal of Global Accounting, 4(2), 52-59.

Tonye Ogiriki \& Andabai Priye W (2017). Exchange rate fluctuation and the performance of the Nigerian economy. International Journal of Advanced Research in Statistics, Management and Finance, 2(1) 15-25.

Umoru, S. G. (2018). Bank depositor protection: The Nigerian experience. NDIC Quarterly Review, 12(2), 64-88. 